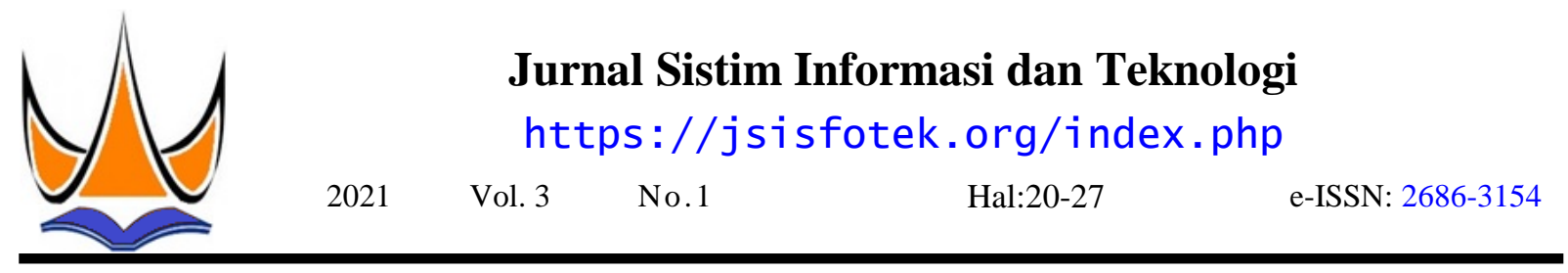

\title{
Sistem Pakar Metode Case Based Reasoning untuk Mengidentifikasi Penyakit Psoriasis
}

\author{
M. Syahputra ${ }^{1 凶}$, Sarjon Defit $^{2}$, Sumijan $^{3}$ \\ ${ }^{1,2,3}$ Universitas Putra Indonesia YPTK Padang \\ syahputra0404@gmai1.com
}

\begin{abstract}
Proriasis is a type of chronic disease of the human skin.problem of psoriasis At the end of the day, theis becoming more interesting because the main cause of this disease has not been found, which has only been found while the cause of psoriasis is genetics. Because the cause is not known for sure, this disease is difficult to cure. Although this disease is not contagious and life-threatening to sufferers, it can damage internal organs if not handled properly. This study aims to determine the level of accuracy in identifying psoriasis in humans. There are several types of symptoms that refer to psoriasis. Furthermore, the data is processed manually with themethod Case Based Reasoning and continued by using a-based expert system software website. The processing stage is to use theprocess, which retrieve is a process of finding the similarities between new cases and existing cases in the knowledge base. The results of the data processing are continued with the calculation of the level of accuracy. The result of testing this method is that there are $100 \%$ of the 12 test data. Based on the accuracy of the identification results of this system, this study is very precise in the level of identifying the level of accuracy of psoriasis in humans. Expert testing system has been able to identify thedisease psoriasis specific. Through thismethod Case Based Reasoning, the level of accuracy that can be obtained is quite accurate and can help skin and genital specialists in improving accuracy in identifyingdiseases Case Based Reasoning in humans.
\end{abstract}

Keywords: Expert Systems, Psoriasis, Case Based Reasoning, Chronic Disease, Human Skin.

\begin{abstract}
Abstrak
Proriasis merupakan salah satu dari jenis penyakit kronis pada kulit manusia. Masalah psoriasis pada akhir ini menjadi lebih menarik karena belum ditemukan penyebab utama munculnya penyakit ini, yang ditemukan baru dugaan sementara penyebab penyakit psoriasis yaitu faktor genetika. Karena penyebabnya belum diketahui pasti maka penyakit ini sulit disembuhkan. Walaupun penyakit ini tidak menular dan mengancam jiwa penderita, namun dapat merusak organ dalam apabila tidak ditangani dengan baik. Penelitian ini bertujuan untuk menentukan tingkat akurasi dalam mengidentifikasi penyakit psoriasis pada manusia. Terdapat beberapa jenis gejala yang merujuk kepada penyakit psoriasis. Selanjutnya data diolah secara manual dengan metode Case Based Reasoning dan dilanjutkan dengan menggunakan software sistem pakar berbasis website. Tahapan pengolahannya adalah dengan menggunakan proses retrieve merupakan proses pencarian kemiripan kasus baru dengan kasus yang ada pada basis pengetahuan. Hasil pengolahan data tersebut dilanjutkan perhitungan tingkat akurasinya. Hasil dari pengujian terhadap metode ini adalah terdapat $100 \%$ dari 12 data pengujian. Berdasarkan akurasi dari hasil identifikasi terhadap sistem ini, maka penelitian ini sangat tepat dalam tingkat mengidentifikasi tingkat akurasi penyakit psoriasis pada manusia. Sistem Pakar pengujian telah dapat mengidentifikasi penyakit psoriasis secara spesifik. Melalui metode Case Based Reasoning ini, tingkat akurasi yang di dapat cukup akurat dan dapat membantu dokter spesialis kulit dan kelamin dalam meningkatkan akurasi untuk mengidentifikasi penyakit Case Based Reasoning pada manusia.
\end{abstract}

Kata Kunci: Sistem Pakar, Psoriasis, Case Based Reasoning, Penyakit Kronis, Kulit Manusia.

(C) 2021 JSisfotek

\section{Pendahuluan}

Psoriasis adalah nama yang diberikan oleh seorang dermatologi asal Vienna, Ferdinan von Hebra pada tahun 1841. Kata psoriasis berasal dari bahasa Yunani yaitu "psora" yang berari "gatal", meskipun sebagian Sistem pakar merupakan salah satu program komputer besar pasien tidak mengeluhkan rasa gatal. Pada masa yang dirancang untuk mengambil keputusan seperti lalu, psoriasis dikenal sebagai bentuk dari penyakit keputusan yang diambil oleh seorang pakar. Sistem kusta. Namun pada tahun 1841 akhirnya penyakit ini pakar adalah sistem perangkat komputer yang diberi nama psoriasis yang dianggap sebagai penyakit menggunakan ilmu, fakta dan teknik berfikir dalam radang kulit kronik yang melibatkan faktor genetik pengambilan keputusan untuk menyelesaikan masalahdalam patogenesisnya.Proriasis merupakan salah satu masalah yang biasanya hanya dapat diselesaikan oleh dari jenis penyakit kronis pada kulit manusia. Masalah seorang pakar dalam bidang yang bersangkutan [2]. psoriasis pada akhir ini menjadi lebih menarik karena belum ditemukan penyebab utama munculnya penyakit ini, yang ditemukan baru dugaan sementara penyebab penyakit psoriasis yaitu faktor genetika. Karena penyebabnya belum diketahui pasti maka penyakit ini sulit disembuhkan. Walaupun penyakit ini tidak menular dan mengancam jiwa penderita, namun dapat merusak organ dalam apabila tidak ditangani dengan baik [1].

Sistem Pakar merupakan sistem yang mencoba untuk mengadopsi pengetahuan manusia kedalam komputer, sehingga komputer bisa membantu menyelesaikan masalah yang biasa diselesaikan oleh para Pakar.

Diterima: 07-10-2020 | Revisi: 21-10-2020 | Diterbitkan: 31-03-2021 | DOI: 10.37034/jsisfotek.v3i1.39 
Adapun beberapa manfaat dari Sistem Pakar yaitu, dapat meningkatkan produktivitas karena Sistem Pakar dapat bekerja lebih cepat daripada manusia, dapat membuat seorang yang awam bekerja seperti layaknya seorang Pakar. Metode dalam penerapan Sistem Pakar ini menggunakan Case Based Reasoning [3].

Metode Case Based Reasoning adalah sebuah metodologi yang menggunakan pengalaman lama untuk dapat mengerti dan menyelesaikan masalah baru [4]. Ada beberapa kelebihan Case Based Reasoning diantaranya, Case Based Reasoning lebih efisien karena menggunakan pengetahuan lama dan mampu mengadaptasi pengetahuan baru, tidak seperti sistem pakar yang selalu membangkitkan rules atau aturanaturan setiap akan menyelesaikan suatu masalah [5].

Beberapa penelitian menggunakan metode Case Based Reasoningadalah Penelitian sistem pakar mendiagnosa penyakit sistem kardiovaskuler pada lansia [6]. Metode Case Based Reasoning dapat digunakan dalam sistem pakar mendiagnosa penyakit sistem kardiovaskuler dan dapat memberikan perhitungan penyelesaian seberapa pasti mengalami penyakit sistem kardiovaskuler. Dengan menerapkan metode case based reasoning dalam mendiagnosa penyakit sistem kardiovaskuler pada lansia dapat menghasilkan perhitungan nilai kepastian yang akurat [7].

Pada penelitian sebelumnya sistem pakar menggunakan metode Case Based Reasoning dalam mendiagnosa penyakit menular pada bayi terdapat adanya inovasi sistem pakar dalam mendiagnoasa penyakit anak dengan menggunakan Cased Based Reasoning. Untuk hasil dari model CBR terdapat Nilai Kasus Tertinggi, Berak cair atau lembek, Tidak bisa minum atau malas minum, Diare 14 hari atau lebih, Tinja berwarna hitam, Ada darah dalam tinja,0.863636364 yang teridentifikasi batuk [8].

Penelitian sistem pakar diagnosa penyakit zika dengan menerapkan metode Case Base Reasoning, dimana metode ini dapat digunakan hanya sebagai mencari nilai kemiripan untuk mencari nilai kepastian bahwa pasien tersebut terdiagnosa atau tidak maka digunakan metode Certainly Factor [9]. Penggunaan metode Case Based Reasoning dan Certainly Factor maka perhitungan nilai $\mathrm{CF}$ mendiagnosa penyakit zika memiliki persentase tingkat keyakinan 97\%, pasien tersebut dinyatakan pasti terkena penyakit zika [10].

Metode CBR adalah metode yang digunakan untuk menyelesaikan suatu masalah dengan menggunakan pengalaman sebelumnya guna menyelesaikan suatu masalah baru dengan tetap memperhatikan aspek kesamaan antara satu dengan beberapa penyelesaian dari permasalahan-permasalahan sebelumnya serta dibangunnya sebuah sistem basisdata untuk menyimpan revisi terhadap suatu solusi permasalahan baru [11].

\section{Metodologi Penelitian}

Metodologi penelitian dipakai di dalam penelitian ini adabeberapa proses dan kerangka dari penelitian ini bisa dilihat pada Gambar 1.

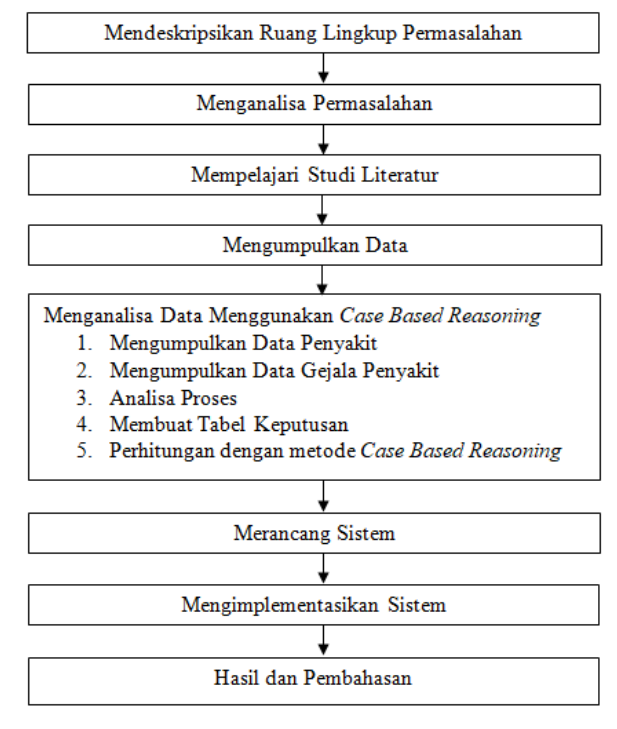

Gambar 1. Kerangka Kerja Penelitian

Berdasarkan kerangka penelitian pada Gambar 1 dijelaskan pada sub bagian berikut.

\subsection{Mendeskripsikan Ruang Lingkup Permasalahan}

Ruang lingkup masalah yang akan diteliti harus ditentukan terlebih dahulu, agar mampu menjelaskan dan menentukan ruang lingkup yang akan diteliti.

\subsection{Menganalisa Masalah}

Menganalisa permasalahan merupakan alur berikutnya agar penelitian yang akan dilakukan dapat memahami masalah yang telah ditentukan batasan masalahnya. Diharapkan dengan masalah yang telah ditentukan dapat menganlisa tersebut dengan baik.

\subsection{Mempelajari Studi Literatur}

Mempelajari literatur juga sangat penting dilakukan agar mempunyai landasan baik secara teoritis yang benar dan jelas yang telah dijelaskan oleh para peneliti dan ahli sebelumnya.

\subsection{Mengumpulkan Data}

Mengumpulkan data dilakukan untuk dapat memperoleh informasi data-data yang dibutuhkan dalam penelitian rangka mencapai tujuan penelitian. Pada metode penelitian ini peneliti menggunakan beberapa metode penelitian dalam pengumpulan data, yaitu field Research dan teknik kalkulasi.

\subsection{Menganalisa Data Menggunakan Metode Case Based Reasoning}


Agar permasalahan penelitian ini dapat dianalisa maka digunakan metode Case Based Reasoning, dengan harapan dapat memberikan solusi dan penangganan terhadap penyakit Psoriasis.

\subsection{Merancang Sistem}

Merancang sistem merupakan rancangan awal sebelum sistem itu digunakan. Hasil dari tahapan ini nantinya menghasilkan sebuah sistem yang dapat digunakan untuk memproses analisa penelitian secara terkomputerisasi

\subsection{Merancang Sistem}

Merancang sistem merupakan rancangan awal sebelum sistem itu digunakan. Hasil dari tahapan ini nantinya menghasilkan sebuah sistem yang dapat digunakan untuk memproses analisa penelitian secara terkomputerisasi.

\subsection{Mengimplementasikan Sistem}

Sistem yang dirancang menggunakan bahasa pemrograman PHP yang menerapkan metode Case Based Reasoning. Implementasi ini dilakukan untuk membandingkan hasil yang didapatkan dengan analisa secara manual dengan sistem.

\subsection{Hasil dan Pembahasan}

Hasil dan pembahasan didasarkan pada hasil penelitian, mulai dilakukan membandingkan keluaran output, maka di dapatkan hasil perhitungan nantinya akan diambil suatu rekomendasi secara tertera pada hasil pembahasan diagnosa penyakit Psoriasis.

\section{Hasil dan Pembahasan}

Pada hasil dan pembahasan terdapat beberapa aktifitas yang dilakukan diantaranya sebagai berikut:

\subsection{Data}

Data yang digunakan pada penelitian ini adalah data penyakit berupa informasi tentang jenis, gejala dan solusi pencegahan terhadap penyakit psoriasis. Data penyakit tersebut diperoleh dari hasil wawancara dengan dokter spesialis kulit dan kelamin.

Berikut merupakan sampel data yang di peroleh langsung dari pakar yang digunakan untuk diproses ke dalam metode Case Based Reasoningdapat dilihat pada Tabel 1.
Tabel 1. Data Pasien Psoriasis

\begin{tabular}{|c|c|c|c|}
\hline $\begin{array}{l}\text { Nama } \\
\text { Pasien }\end{array}$ & Usia & Gejala & Diagnosa \\
\hline Pasien 1 & 22 tahun & $\begin{array}{l}\text { - Kulit yang menebal } \\
\text { - Kulit kering dan pecah-pecah } \\
\text { hingga berdarah } \\
\text { - Rasa gatal dan perih terbakar } \\
\text { pada area yang terkena } \\
\text { - Area kulit yang berwarna } \\
\text { gelap bisa bertambah gelap, } \\
\text { berubah warna menjadi abu- } \\
\text { abu keunguan atau coklat } \\
\text { gelap }\end{array}$ & $\begin{array}{l}\text { Psoriasis } \\
\text { Plak }\end{array}$ \\
\hline Pasien 2 & 30 tahun & $\begin{array}{l}\text { - Kulit tebal berwarna merah di } \\
\text { kulit kepala } \\
\text { - Kulit kepala terkelupas }\end{array}$ & $\begin{array}{l}\text { Psoriasis } \\
\text { Arthritis }\end{array}$ \\
\hline Pasien 3 & 42 tahun & $\begin{array}{l}\text { - Kemunculan bintik-bintik } \\
\text { merah kecil (pustula) yang } \\
\text { menyebar merata di } \\
\text { permukaan kulit } \\
\text { - Tekstur bintik tidak setebal } \\
\text { plak pada psoriasis vulgaris } \\
\text { - Ruam memerah menyerupai } \\
\text { tetesan air } \\
\text { - Bentuk psoriasis ini paling } \\
\text { sering muncul setelah terjadi } \\
\text { infeksi pada kulit, seperti } \\
\text { akibat infeksi bakteri } \\
\text { streptococcus, atau infeksi } \\
\text { virus cacar air }\end{array}$ & $\begin{array}{l}\text { Psoriasis } \\
\text { Guttata }\end{array}$ \\
\hline Pasien 4 & 28 tahun & $\begin{array}{l}\text { - Bercak merah yang terlihat } \\
\text { halus di kulit } \\
\text { - Peradangan pada kulit yang } \\
\text { akan memburuk saat } \\
\text { bergesekan dan berkeringat } \\
\text { - Munculnya lapisan putih } \\
\text { keperakan yang sangat tipis }\end{array}$ & $\begin{array}{l}\text { Psoriasis } \\
\text { Inversa }\end{array}$ \\
\hline Pasien 5 & 32 tahun & $\begin{array}{l}\text { - Naik-turunnya temperatur } \\
\text { tubuh dengan cepat } \\
\text { - Pustula atau bintil-bintil kulit } \\
\text { berisi nanah khas psoriasis } \\
\text { pustulosa juga bisa muncul } \\
\text { pada bagian kulit yang } \\
\text { meradang. } \\
\text { - Peningkatan detak jantung }\end{array}$ & $\begin{array}{l}\text { Psoriasis } \\
\text { Eritrodermi } \\
k\end{array}$ \\
\hline Pasien 6 & 35 Tahun & $\begin{array}{l}\text { - Peningkatan detak jantung } \\
\text { - Nyeri sendi (psoriasis } \\
\text { arthritis) } \\
\text { - Ukuran plak atau bercak } \\
\text { beragam, mulai dari sebesar } \\
\text { koin hingga seukuran telapak } \\
\text { tangan. }\end{array}$ & $\begin{array}{l}\text { Psoriasis } \\
\text { Pustulosa }\end{array}$ \\
\hline
\end{tabular}

Penyakit yang diteliti dalam penelitian tersebut merupakan tentang jenis penyakit Psoriasis pada kucing bisa dilihat pada Tabel 2.

Tabel 2. Data Jenis-Jenis Penyakit Psoriasis

\begin{tabular}{lll}
\hline No & Kode Penyakit & Nama Penyakit \\
\hline 1 & P01 & Psoriasis Plak \\
2 & P02 & Psoriasis Psoriasis Arthritis \\
3 & P03 & Psoriasis Guttata \\
4 & P04 & Psoriasis Inversa \\
5 & P05 & Psoriasis Eritrodermik \\
6 & P06 & Psoriasis Pustulosa \\
\hline
\end{tabular}

Berdasarkan Tabel 2 terdapat 6 jenis penyakit psoriasis dan diberikan kode G01-G18. Penyakit psoriasis mempunyai gejala yang mengarah pada jenis penyakit yang dirasakan. Dalam penelitian penyakit psoriasis tersebut, ada 18 gejala, seperti pada Tabel 3. 
Tabel 3. Data Gejala Penyakit Psoriasis

\begin{tabular}{|c|c|c|}
\hline No & $\begin{array}{l}\text { Kode } \\
\text { Gejala }\end{array}$ & Nama Penyakit \\
\hline 1 & G01 & Kulit yang menebal \\
\hline 2 & G02 & Kulit kering dan pecah-pecah hingga berdarah \\
\hline 3 & G03 & $\begin{array}{l}\text { Rasa gatal dan perih terbakar pada area yang } \\
\text { terkena }\end{array}$ \\
\hline 4 & G04 & $\begin{array}{l}\text { Area kulit yang berwarna gelap bisa bertambah } \\
\text { gelap, berubah warna menjadi abu-abu keunguan } \\
\text { atau coklat gelap. }\end{array}$ \\
\hline 5 & G05 & Kulit tebal berwarna merah di kulit kepala \\
\hline 6 & G06 & Kulit kepala terkelupas \\
\hline 7 & G07 & $\begin{array}{l}\text { Kemunculan bintik-bintik merah kecil (pustula) } \\
\text { yang menyebar merata di permukaan kulit }\end{array}$ \\
\hline 8 & G08 & $\begin{array}{l}\text { Tekstur bintik tidak setebal plak pada Psoriasis } \\
\text { vulgaris. }\end{array}$ \\
\hline 9 & G09 & Ruam memerah menyerupai tetesan air, \\
\hline 10 & G10 & $\begin{array}{l}\text { Bentuk psoriasis ini paling sering muncul setelah } \\
\text { terjadi infeksi pada kulit, seperti akibat infeksi } \\
\text { bakteri streptococcus, atau infeksi virus cacar air. }\end{array}$ \\
\hline 11 & G11 & Bercak merah yang terlihat halus di kulit. \\
\hline 12 & G12 & $\begin{array}{l}\text { Peradangan pada kulit yang akan memburuk saat } \\
\text { bergesekan dan berkeringat }\end{array}$ \\
\hline 13 & G13 & $\begin{array}{l}\text { Munculnya lapisan putih keperakan yang sangat } \\
\text { tipis }\end{array}$ \\
\hline 14 & G14 & Naik-turunnya temperatur tubuh dengan cepat \\
\hline 15 & G15 & $\begin{array}{l}\text { Pustula atau bintil-bintil kulit berisi nanah khas } \\
\text { Psoriasis pustulosa juga bisa muncul pada bagian } \\
\text { kulit yang meradang. }\end{array}$ \\
\hline 16 & G16 & Peningkatan detak jantung \\
\hline 17 & G17 & Nyeri sendi (Psoriasis arthritis) \\
\hline 18 & G18 & $\begin{array}{l}\text { Ukuran plak atau bercak beragam, mulai dari } \\
\text { sebesar koin hingga seukuran telapak tangan }\end{array}$ \\
\hline
\end{tabular}

Tabel2mendeskripsikan gejalayangdigunakan pada penelitian ini sebanyak 18 gejala dengan pemberian kodedari G01-G18.

\section{2. Analisa Sistem}

Perhitungan Sistem Pakar dengan menggunakan proses Case Based Reasoning yaitu diawali dari beberapa fakta mengenaisuatugejala yang disampaikan oleh user sebagai input ke dalam sistem. Berikut algoritma proses dalam mendiagnosa penyakit Psoriasis berdasarkan alur metode Case Based Reasoning pada Gambar 2.

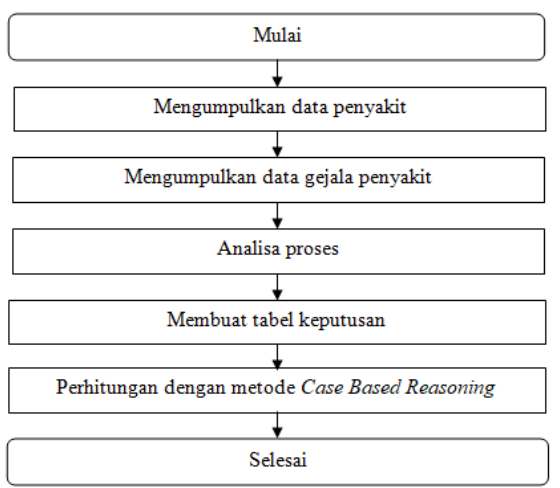

Gambar 2. Flowchart Case Based Reasoning

Berdasarkan flowchart algoritma Case Based Reasoning pada Gambar 2, maka dapat digambarkan proses kerja darisistem dengan Case Based Reasoning sebagai berikut:

\subsubsection{Analisa Metode Case Based Reasoning}

Tahapan analisa proses dilakukan dengan menggunakan metode Case Based Reasoning terdapat empat tahapan proses didalamnya, yaitu retrive, reuse, revise dan retain. Sistem ini pada umumnya berpedoman pada basis pengetahuan yang dimiliki oleh sistem itu sendiri.Sebagai contoh, berikut dialog user dengan sistem pakar serta data gejala penyakit psoriasis pada aplikasi Sistem Pakar dapat dilihat pada Tabel 4.

Tabel 4. Tabel Fakta Gejala Pasien

\begin{tabular}{|c|c|c|}
\hline $\begin{array}{l}\text { Kode } \\
\text { Gejala }\end{array}$ & Pertanyaan & Jawaban \\
\hline G01 & Kulit yang menebal & Ya \\
\hline G02 & Kulit kering dan pecah-pecah hingga berdarah & Ya \\
\hline G03 & $\begin{array}{l}\text { Rasa gatal dan perih terbakar pada area yang } \\
\text { terkena }\end{array}$ & Ya \\
\hline G04 & $\begin{array}{l}\text { Area kulit yang berwarna gelap bisa bertambah } \\
\text { gelap, berubah warna menjadi abu-abu } \\
\text { keunguan atau coklat gelap. }\end{array}$ & Tidak \\
\hline G05 & Kulit tebal berwarna merah di kulit kepala & Tidak \\
\hline G06 & Kulit kepala terkelupas & Tidak \\
\hline G07 & $\begin{array}{l}\text { Kemunculan bintik-bintik merah kecil (pustula) } \\
\text { yang menyebar merata di permukaan kulit }\end{array}$ & Ya \\
\hline G08 & $\begin{array}{l}\text { Tekstur bintik tidak setebal plak pada Psoriasis } \\
\text { vulgaris }\end{array}$ & Tidak \\
\hline G09 & Ruam memerah menyerupai tetesan air & Tidak \\
\hline G10 & $\begin{array}{l}\text { Bentuk psoriasis ini paling sering muncul } \\
\text { setelah terjadi infeksi pada kulit, seperti akibat } \\
\text { infeksi bakteri streptococcus, atau infeksi virus } \\
\text { cacar air }\end{array}$ & Ya \\
\hline G11 & Bercak merah yang terlihat halus di kulit & Ya \\
\hline G12 & $\begin{array}{l}\text { Peradangan pada kulit yang akan memburuk } \\
\text { saat bergesekan dan berkeringat }\end{array}$ & Tidak \\
\hline G13 & $\begin{array}{l}\text { Munculnya lapisan putih keperakan yang sangat } \\
\text { tipis }\end{array}$ & Tidak \\
\hline G14 & Naik-turunnya temperatur tubuh dengan cepat & Tidak \\
\hline G15 & $\begin{array}{l}\text { Pustula atau bintil-bintil kulit berisi nanah khas } \\
\text { psoriasis pustulosa juga bisa muncul pada } \\
\text { bagian kulit yang meradang. }\end{array}$ & Tidak \\
\hline G16 & Peningkatan detak jantung & Tidak \\
\hline G17 & Nyeri sendi (Psoriasis arthritis) & Ya \\
\hline G18 & $\begin{array}{l}\text { Ukuran plak atau bercak beragam, mulai dari } \\
\text { sebesar koin hingga seukuran telapak tangan. }\end{array}$ & Tidak \\
\hline
\end{tabular}

3.2.2 Kasus Baru

Berikut merupakan kasus baru yang didapatkan dari hasil diagnose awal terhadap penyakit psoriasis seperti Tabel 5.

Tabel 5. Tabel Kasus Baru

\begin{tabular}{|c|c|c|}
\hline Fakta & Gejala yang dirasakan & Bobot \\
\hline G01 & Kulit yang menebal & 5 \\
\hline G02 & $\begin{array}{l}\text { Kulit kering dan pecah-pecah hingga } \\
\text { berdarah }\end{array}$ & 5 \\
\hline G03 & $\begin{array}{l}\text { Rasa gatal dan perih terbakar pada area } \\
\text { yang terkena }\end{array}$ & 1 \\
\hline G07 & $\begin{array}{l}\text { Kemunculan bintik-bintik merah kecil } \\
\text { (pustula) yang menyebar merata di } \\
\text { permukaan kulit }\end{array}$ & 1 \\
\hline G10 & $\begin{array}{l}\text { Bentuk psoriasis ini paling sering } \\
\text { muncul setelah terjadi infeksi pada kulit, } \\
\text { seperti akibat infeksi bakteri } \\
\text { streptococcus, atau infeksi virus cacar } \\
\text { air. }\end{array}$ & 1 \\
\hline G11 & Bercak merah yang terlihat halus di kulit & 1 \\
\hline G17 & Nyeri sendi (Psoriasis arthritis) & 5 \\
\hline
\end{tabular}

\subsubsection{Proses Retrieve}

Proses retrieve merupakan proses pencarian kemiripan kasus baru dengan kasus yang ada pada basis

Jurnal Sistim Informasi dan Teknologi Vol. 3 No. 1 (2021) 20-27 


\section{Syahputra, Sarjon Defit, Sumijan.}

pengetahuan. Pencarian kemiripan tersebut dilakukan Similiarity $(x, x)=\frac{s 1 * w 1+s 2 * w 2+\cdots s n * w n}{w 1+w 2+\cdots w n}$ dengan cara mencocokkan gejala yang di inputkan oleh pengguna dengan gejala yang ada pada basis pengetahuan. Pada proses retrieve ini akan dilakukan pembobotan dengan menggunakan algoritma Nearest Neighbour Retrieval.

$$
\text { Similiarity }=\frac{s 1 * w 1+s 2 * w 2+\cdots s n * w n}{w 1+w 2+\cdots w n}
$$

\section{Perhitungan Kasus Psoriasis Plak}

$$
\begin{aligned}
& =0 \\
& =0 \%
\end{aligned}
$$

Dari perhitungan kasus diatas memiliki tingkat kemiripan dengan kasus lama. sehingga dari perhitungan similarity sebesar $0 \%$.

\section{Perhitungan Kasus Psoriasis Guttata}

Perhitungan kasus Psoriasis Plak dari sistem yang Perhitungan kasus Psoriasis Guttata dari sistem yang diteliti disajikan pada Gambar 3.

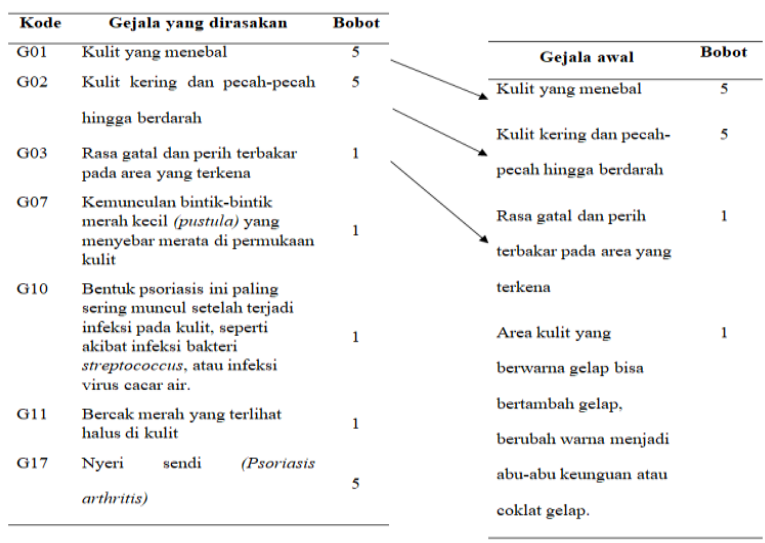

Gambar 3. Perhitungan Psoriasis Plak

Similiarity $(x, x)=\frac{s 1 * w 1+s 2 * w 2+\cdots s n * w n}{w 1+w 2+\cdots w n}$

$$
=\frac{(1 * 5)+(1 * 5)+(1 * 1)}{5+5+1+1}=0.91=91 \%
$$

Dari perhitungan kasus diatas memiliki tingkat kemiripan dengan kasus lama. sehingga dari

\begin{tabular}{|c|c|c|c|c|}
\hline Kode & Gejala yang dirasakan & Bobot & Gejala awal & Bobot \\
\hline G01 & Kulit yang menebal & 5 & Kemunculan bintik- & 1 \\
\hline G02 & $\begin{array}{l}\text { Kulit kering dan pecah-pecah } \\
\text { hingga berdarah }\end{array}$ & 5 & $\begin{array}{l}\text { bintik merah kecil } \\
\text { (pustula) yang } \\
\text { menyebar merata di }\end{array}$ & \\
\hline G03 & $\begin{array}{l}\text { Rasa gatal dan perih terbakar } \\
\text { pada area yang terkena }\end{array}$ & 1 & permukaan kulit & \\
\hline G07 & $\begin{array}{l}\text { Kemunculan bintik-bintik } \\
\text { merah kecil (pustula) yang } \\
\text { menyebar merata di permukaan }\end{array}$ & 1 & $\begin{array}{l}\text { Tekstur bintik tidak } \\
\text { setebal plak pada } \\
\text { psoriasis vulgaris. }\end{array}$ & 5 \\
\hline & & & Ruam memerah & 1 \\
\hline G10 & $\begin{array}{l}\text { Bentuk Psoriasis ini paling } \\
\text { sering muncul setelah terjadi }\end{array}$ & & menyerupai tetesan air, & \\
\hline & $\begin{array}{l}\text { infeksi pada kulit, seperti } \\
\text { akibat infeksi bakteri } \\
\text { streptococcus, atau infeksi } \\
\text { virus cacar air. }\end{array}$ & 1 & $\begin{array}{l}\text { Bentuk Psoriasis ini } \\
\text { paling sering muncul } \\
\text { setelah terjadi infeksi }\end{array}$ & 1 \\
\hline G11 & $\begin{array}{l}\text { Bercak merah yang terlihat } \\
\text { halus di kulit }\end{array}$ & 1 & $\begin{array}{l}\text { pada kulit, seperti } \\
\text { akibat infeksi bakteri }\end{array}$ & \\
\hline G17 & $\begin{array}{l}\text { Nyeri sendi (Psoriasis } \\
\text { arthritis) }\end{array}$ & 5 & $\begin{array}{l}\text { streptococcus, atau } \\
\text { infeksi virus cacar air. }\end{array}$ & \\
\hline
\end{tabular}
perhitungan similarity sebesar $91 \%$.

2. Perhitungan Kasus Psoriasis Arthritis diteliti disajikan pada Gambar 5.

Gambar 5. Perhitungan Psoriasis Guttata

Perhitungan kasus Psoriasis Arthritis dari sistem yang diteliti disajikan pada Gambar 4.

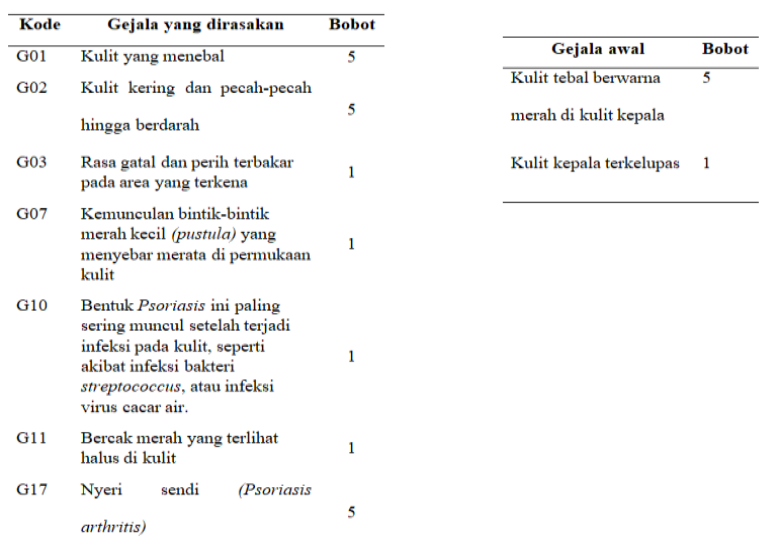

$$
\begin{aligned}
\operatorname{Similiarity}(x, x)= & \frac{s 1 * w 1+s 2 * w 2+\cdots s n * w n}{w 1+w 2+\cdots w n} \\
& =\frac{(1 * 1)+(1 * 1)}{1+5+1+1} \\
& =0.25=25 \%
\end{aligned}
$$

Dari perhitungan kasus diatas memiliki tingkat kemiripan dengan kasus lama. sehingga dari perhitungan similarity sebesar $25 \%$.

\section{Perhitungan Kasus Psoriasis Inversa}

Perhitungan kasus Psoriasis Inversa dari sistem yang diteliti disajikan pada Gambar 6. 


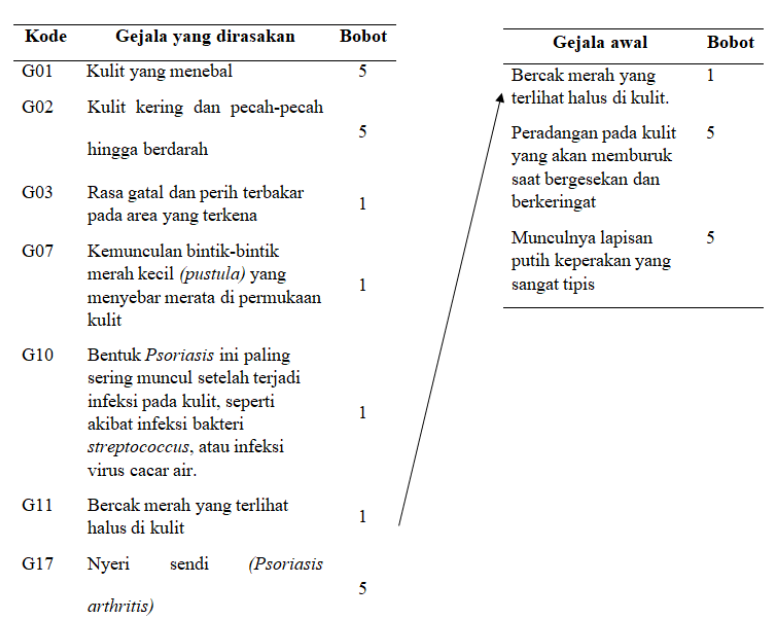

Gambar 6. Perhitungan Psoriasis Inversa

$$
\begin{aligned}
\text { Similiarity }(x, x)=\frac{s 1 * w 1+s 2 * w 2+\cdots s n * w n}{w 1+w 2+\cdots w n} \\
=\frac{(1 * 1)}{1+5+5} \\
=0.09=9 \%
\end{aligned}
$$

Dari perhitungan kasus diatas memiliki tingkat kemiripan dengan kasus lama. sehingga dari perhitungan similarity sebesar $9 \%$.

\section{Perhitungan Kasus Psoriasis Eritrodermik}

\begin{tabular}{|c|c|c|}
\hline Kode & Gejala yang dirasakan & Bobot \\
\hline G01 & Kulit yang menebal & 5 \\
\hline $\mathrm{G} 02$ & $\begin{array}{l}\text { Kulit kering dan pecah-pecah } \\
\text { hingga berdarah }\end{array}$ & 5 \\
\hline $\mathrm{G} 03$ & $\begin{array}{l}\text { Rasa gatal dan perih terbakar } \\
\text { pada area yang terkena }\end{array}$ & 1 \\
\hline G07 & $\begin{array}{l}\text { Kemunculan bintik-bintik } \\
\text { merah kecil (pustula) yang } \\
\text { menyebar merata di permukaan } \\
\text { kulit }\end{array}$ & 1 \\
\hline G10 & $\begin{array}{l}\text { Bentuk Psoriasis ini paling } \\
\text { sering muncul setelah terjadi } \\
\text { infeksi pada kulit, seperti } \\
\text { akibat infeksi bakteri } \\
\text { streptococcus, atau infeksi } \\
\text { virus cacar air. }\end{array}$ & 1 \\
\hline G11 & $\begin{array}{l}\text { Bercak merah yang terlihat } \\
\text { halus di kulit }\end{array}$ & 1 \\
\hline G17 & Nyeri sendi (psoriasis arthritis) & 5 \\
\hline
\end{tabular}

Perhitungan kasus Psoriasis Eritrodermik dari sistem 3.2.4 Proses Reuse yang diteliti disajikan pada Gambar 7.

\begin{tabular}{ll}
\hline \multicolumn{1}{c}{ Gejala awal } & Bobot \\
\hline $\begin{array}{l}\text { Naik-turunnya } \\
\text { temperatur tubuh } \\
\text { dengan cepat }\end{array}$ & 1 \\
$\begin{array}{l}\text { Pustula atau bintil- } \\
\text { bintil kulit berisi nanah }\end{array}$ & 5 \\
khas psoriasis \\
pustulosa juga bisa \\
muncul pada bagian \\
kulit yang meradang. \\
$\begin{array}{l}\text { Peningkatan detak } \\
\text { jantung }\end{array}$ & 1 \\
\hline
\end{tabular}

Gambar 7. Perhitungan Psoriasis Eritrodermik

$$
\begin{aligned}
\operatorname{Similiarity}(x, x)= & \frac{s 1 * w 1+s 2 * w 2+\cdots s n * w n}{w 1+w 2+\cdots w n} \\
& =0 \\
& =0 \%
\end{aligned}
$$

Dari perhitungan kasus diatas memiliki tingkat kemiripan dengan kasus lama. sehingga dari Berdasarkan hasil perhitungan dengan menggunakan perhitungan similarity sebesar $0 \%$.

6. Perhitungan Kasus Psoriasis Pustulosa

Perhitungan kasus Psoriasis Pustulosa dari sistem yang diteliti disajikan pada Gambar 8.

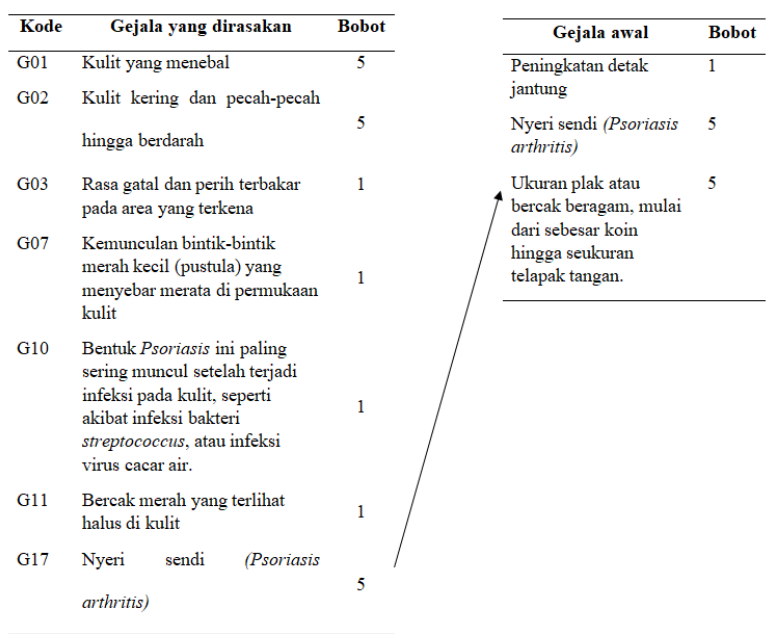

Gambar 8. Perhitungan Psoriasis Pustulosa

Similiarity $(x, x)=\frac{s 1 * w 1+s 2 * w 2+\cdots s n * w n}{w 1+w 2+\cdots w n}$

$$
\begin{aligned}
& =\frac{(1 * 5)}{1+5+5} \\
& =0.45=45 \%
\end{aligned}
$$

Dari perhitungan kasus diatas memiliki tingkat kemiripan dengan kasus lama. sehingga dari perhitungan similarity sebesar $45 \%$.

Dari perhitungan kasus diatas, kasus yang memiliki bobot kemiripan tertinggi dengan kasus lama adalah Psoriasis Plak dengan nilai $91 \%$. Pada proses reuse, solusi yang diberikan adalah solusi dengan bobot kemiripan kasus yang ada pada pengetahuan dengan kasus baru yang paling tinggi.

\subsubsection{Proses Revise}

Proses ini dilakukan untuk memperbaiki solusi yang diusulkan kemudian mengujinya pada kasus nyata (simulasi) dan diperlukan kembali untuk memperbaiki solusi tersebut agar cocok dengan kasus yang baru.

\subsubsection{Proses Retain}

Proses retain yaitu (menyimpan) bagian-bagian dari pengalaman tersebut yang mungkin berguna untuk memecahkan masalah di masa yang akan datang.

Proses ini terdiri dari memilih informasi apa dari kasus yang akan disimpan, disimpan dalam bentuk apa, cara menyusun kasus untuk agar mudah untuk menemukan masalah yang mirip, dan bagaimana mengintegrasikan kasus baru pada struktur memori.

\subsubsection{Hasil}

metode Case Based Reasoning, maka diperoleh fakta baru penyakit yang diderita oleh kelima pasien seperti pada Tabel 6. 
M. Syahputra, Sarjon Defit, Sumijan.

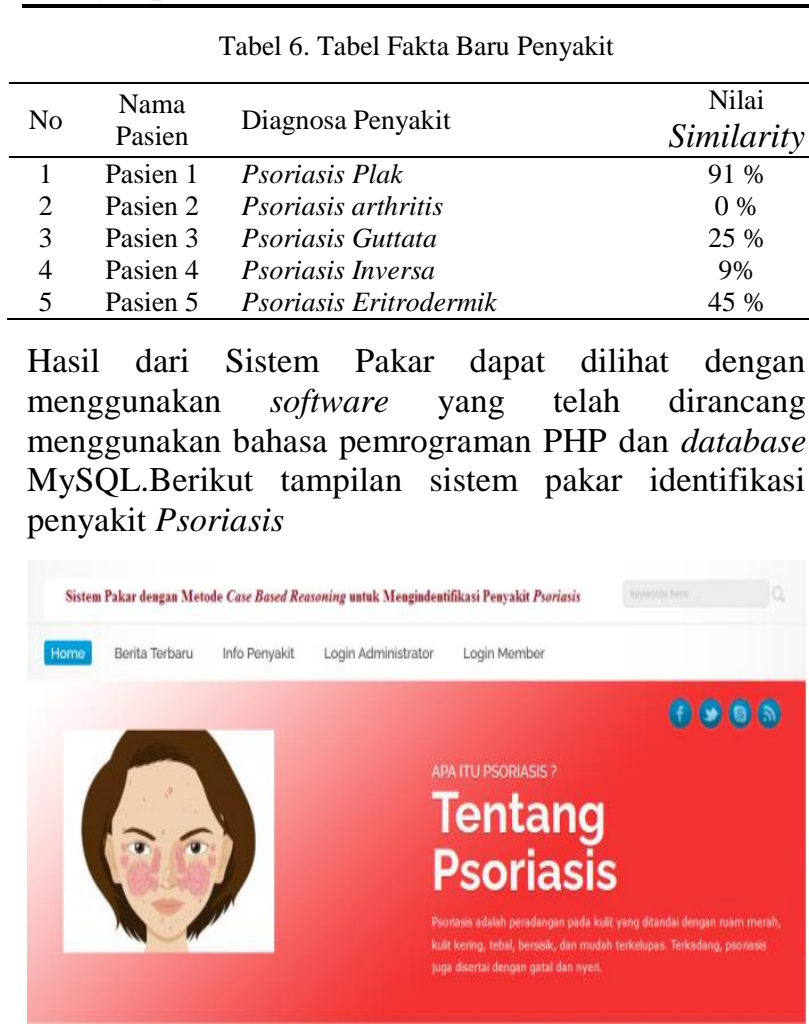

Gambar 9. Tampilan Halaman Utama

Gambar 9 menunjukkan halaman utama untuk menampilkan semua menu yang bisa digunakan oleh user atau calon pasien.

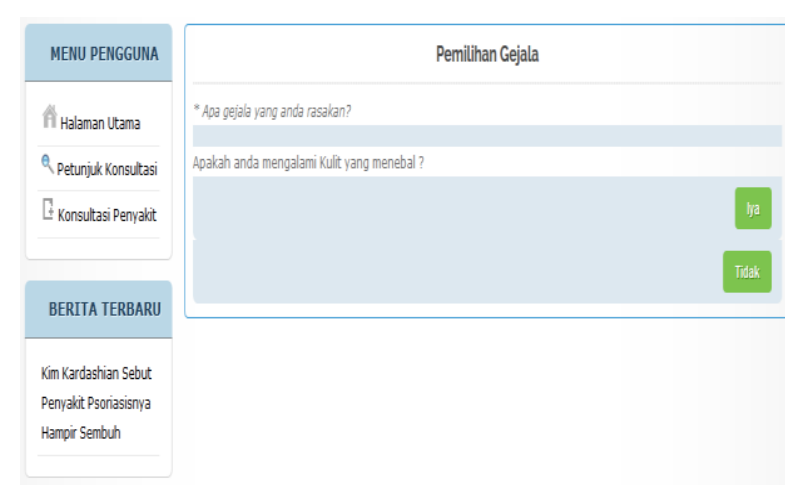

Gambar 10. Tampilan Menu Konsultasi

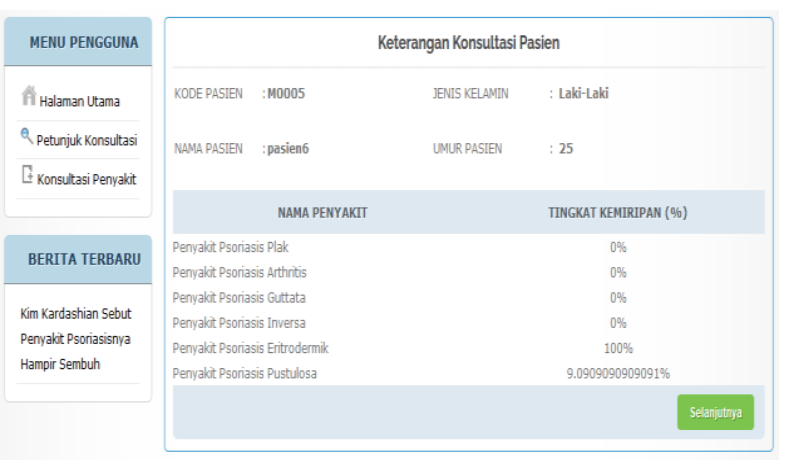

Gambar 11. Tampilan Hasil Konsultasi Pasien

Selanjutnya dilakukan pengujian terhadap 12 data pasien dengan membandingan dengan hasil dari pakar untuk melihat tingkat akurasi hasil. Cara yang digunakan dalam menentukan tingkat akurasi yaitu dengan rumus probalilitas.

Rumus Probabilitas : $=P_{(E)}=\frac{X}{N} \mathrm{x} 100 \%$

Dimana $\mathrm{P}$ merupakan nilai dari probabilitas, $\mathrm{E}$ adalah event, $\mathrm{x}$ merupakan jumlah kejadian yang terjadi, dan $\mathrm{N}$ merupakan jumlah seluruh kejadian. Hasil pengujian Sistem Pakar ini terhadap 12 data pasien adalah:

$$
\begin{gathered}
\mathrm{P}_{\text {jumlah }} \text { (Akurat) } \quad=\mathrm{X} / \mathrm{N} \times 100 \% \\
=12 / 12 \times 100 \% \\
=100 \%
\end{gathered}
$$

Setelah dilakukan pengujian dan perhitungan tingkat akurasi sistem, maka diperoleh tingkat akurasi yang sangat baik dari hasil perhitungan sistem dengan keputusan pakar sebesar 100\% dari 12 data pengujian. Berdasarkan tingkat akurasi dari hasil identifikasi terhadap sistem, maka penelitian ini sangat tepat dalam mendiagnosa penyakit psoriasissecara tepat.

\section{Kesimpulan}

Aplikasi Sistem Pakar yang dibangun dapat mengurangi keterlambatan penanganan medis yang mengakibatkan resiko kematian pada penderita penyakit $p$ soriasis.Sistem Pakar ini dapat memberikan wawasan dan pengetahuan terhadap masyarakat tentang gejala-gejala, faktor penyebab, solusi dan pencegahan Pada halaman ini menampilkan proses konsultasi gejala-gejala, faktor peny
pasien dengan Sistem Pakar, yaitu pasien akan dari penyakit psoriasis. merespon pertanyaan dengan memasukkan jawaban ya atau tidak berdasarkan gejala yang mungkin dialami. Setelah pasien berkonsultasi dengan Sistem Pakar, maka akan ditampilkan hasil konsultasi pasien seperti pada Gambar 11.

\section{Daftar Rujukan}

[1] Belachew, E. B., \& Tamiru, H., K. (2019). Chronic Kidney Disease Diagnosis Model Based on Case Based Reasoning. International Journal of Engineering and Advanced Technology (IJEAT), 9(2). DOI: https://doi.org/10.35940/ijeat.B3624.129219

[2] Fatmawatie, B. D., \& Baizal, Z. K. A. (2018). Tourism Recommender System Using Case Based Reasoning Approach (Case Study: Bandung Raya Area). In Journal of Physics: Conference Series, 1192(1), IOP Publishing. DOI: https://doi.org/10.1088/1742-6596/1192/1/012050 .

[3] Hardianto, R., \& Kusuma, C. (2019). Rancang Bangun Sistem Pakar Penentuan Kepribadian. Jurnal Sistem Komputer dan Informatika (JSON), 1(1), 45-51. DOI: http://dx.doi.org/10.30865/json.v1i1.1385 . 
[4] Lin, K. S. (2020). A Case-Based Reasoning System For Interior Design Using A New Cosine Similarity Retrieval Algorithm. Journal of Information and Telecommunication, 4(1), 91-104. DOI: https://doi.org/10.1080/24751839.2019.1700338 .

[5] Minarni., Warman, I., \& Yuhendra. (2018). Implementasi CaseBased Reasoning Sebagai Metode Inferensi pada Sistem Pakar Identifikasi Penyakit Tanaman Jagung. Jurnal TeknoIf, 6(1). DOI: http://dx.doi.org/10.21063\%2Fjtif.2018.V6.1.1-7 .

[6] Purbaningtyas, R. (2019). Analisa Denyut Jantung Menggunakan Aplikasi Mobile Self Integrated BioInformatics System. Jurnal Teknologi Informasi dan Terapan (J-TIT), 6(2), 67-74.

[7] Zaw, S. K., \& Vasupongayya, S. (2019). A Case-Based Reasoning Approach for Automatic Adaptation of Classifiers in Mobile Phishing Detection. Journal of Computer Networks and Communications, 2019 .

DOI: https://doi.org/10.1155/2019/7198435 .

[8] Sheng, Y., Zhang, J., Wang, C., Yin, F. F., Wu, Q. J., \& Ge, Y (2019). Incorporating Case-Based Reasoning For Radiation
Therapy Knowledge Modeling: A Pelvic Case Study. Technology In Cancer Research \& Treatment. DOI: http://dx.doi.org/10.1177/1533033819874788 .

[9] Silmina, E. P., \& Wardoyo, R. (2018). Aplikasi Case Based Reasoning Untuk Identifikasi Serangan Hama Pada Tanaman Jeruk. Transmisi, 20(3), 96-104. DOI: https://doi.org/10.14710/transmisi.20.3.96-104 .

[10] Triswardani, G., \& Hasibuan, N. A. (2018). Penerapan Case Based Reasoning (Cbr) Pada Sistem Pakar Diagnosa Penyakit Otitis Media Supuratif Kronis (OMSK) Pada Orang Dewasa. Jurnal Media Informatika Budidarma, 2(2). DOI: http://dx.doi.org/10.30865/mib.v2i2.597 .

11]Wahyudi, E., \& Pradasari, N. I. (2018). Case Based Reasoning untuk Diagnosis Penyakit Jantung Menggunakan Metode Minkowski Distance. INTECOMS: Journal of Information Technology and Computer Science, 1(1), 119-123. DOI: http://dx.doi.org/10.31539/intecoms.v1i1.170 